\title{
DISTRIBUTION AND IDENTIFICATION OF FRUIT FLIES (DIPTERA: TEPHRITIDAE) ATTRACTED ON METHYL EUGANOL AND CUE LURE IN CENTRAL BANGKA REGENCY, BANGKA BELITUNG
}

\author{
Herry Marta Saputra ${ }^{1}$ \& Budi Afriyansyah ${ }^{2}$ \\ ${ }^{1}$ Department of Agrotechnology, Faculty of Agriculture, Fisheries, and Biology, Universitas Bangka Belitung, Indonesia \\ Jl. Kampus Peradaban Kampus Terpadu UBB Balunijuk Merawang Bangka 33172 \\ ${ }^{2}$ Departement of Biology, Faculty of Agriculture, Fisheries, and Biology, Universitas Bangka Belitung, Indonesia \\ J1. Kampus Peradaban Kampus Terpadu UBB Balunijuk Merawang Bangka 33172 \\ E-mail: hartsaputra3103@gmail.com
}

Manuscript received: 10 December 2020. Revision accepted: 3 March 2021.

\begin{abstract}
Distribution and identification of fruit flies (Diptera: Tephritidae) attracted on methyl euganol and cue lure in Central Bangka Regency, Bangka Belitung. Not all fruit flies species of Dacini tribe were pests to fruit and fleshy vegetables. Central Bangka Regency is one of the citrus producer in the Bangka Belitung Islands Province. Information about this fruit flies in this area was limited. This study aimed to make inventory and identification of fruit flies species of the Dacini tribe in Central Bangka Regency, Bangka Belitung. The research was conducted in Nibung, Penyak, and Terentang Villages in Central Bangka Regency, Bangka Islands. Lynfield traps were installed in a citrus cultivation area about $1.5 \mathrm{~m}$ above ground level. Lynfield traps were treated with the attractant and deltamethrin $(2: 1 ; \mathrm{v} / \mathrm{v})$ on dental cotton. Methyl eugenol and cue lure were used to attract the male fruit flies. In Central Bangka Regency, 3 genera and 14 species of fruit flies were obtained from the tribe Dacini. The fruit fly species of Bactrocera atrifemur, B. carambolae, B. dorsalis, B. occipitalis, and B. umbrosa were caught in the methyl eugenol attractant trap. Meanwhile, the fruit fly species of B. albistrigata, B. fuscitibia, B. melastomatos, B. neocognata, B. nigrotibialis, Dacus nanggalae, Zeugodacus apicalis, Z. caudatus, and Z. cucurbitae were caught in the cue lure attractant trap. The fruit flies obtained from the two different attractants were used to develop dichotomous keys.
\end{abstract}

Key words: citrus, cue lure, delthametrin, lynfield trap, methyl eugenol

\section{INTRODUCTION}

Fruit flies (Diptera: Tephritidae) are important pest of commercial horticultural crops in tropical and subtropical countries. This pest attacks fruit and fleshy vegetables (Vargas et al., 2015). Fruit flies disturbance in the horticultural sector would have impacts on the socio-economic sector of a country such as threats to food security, the food industry, jobs, farmers' income and foreign exchange (Vargas et al., 2007; Kwasi, 2008; Vargas et al., 2015). Affected fruits could reduced its economic value due to the quality damage and quantity decrease at harvest. Fruits that were infested with fruit flies would be rotten, less aesthetics, has lower nutritional content, change in taste and aroma, and susceptable to important post-harvest fungi such as Penicillium digitatum Sacc. or P. notatum (Omoloye et al., 2016; Ni et al., 2020). Fruit flies directly damages host fruits and indirectly caused the loss of export opportunities for horticultural products due to quarantine regulation from importing countries to prevent the entry of fruit flies into the country (Vargas et al., 2007).

Doorenweerd et al. (2018) reported that one of the fruit fly families reported to attack fruit and vegetable crops was Dacini tribe. The Dacini tribe was divided into 4 genera: Bactrocera Macquart, Dacus Fabricius, Monacrostichus Bezzi, and Zeugodacus Hendel. There were 932 species of Dacini fruit flies worldwide. In the Asia Pacific region there were 730 species, while in Africa there were 207 species. Only 10\% from 932 species of Dacini tribe were reported as important pests of commercial fruit and vegetable crops. Vargas et al. (2015) classified the species of Bactrocera into 4 categories based on the level of threat of fruit flies, namely categories $\mathrm{A}, \mathrm{B}, \mathrm{C}$, and $\mathrm{D}$. 
The diversity of fruit fly species could be different from one region to another. The presence of fruit fly species in an area could be detected by installing attractant traps. Some of the attractants used for Dacini fruit flies survey are methyl eugenol (ME) and cue lure (Drew \& Romig, 2016). In Indonesia, there were more than 120 species of tribe Dacini fruit flies (Drew \& Romig, 2012a). Fruit flies on the Bangka Island that have been known include Bactrocera atrifemur, $B$. albistrigata, B. carambolae, B. dorsalis, B. limbifera, B. umbrosa, B. occipitalis, Dacus nanggalae, Zeugodacus cucurbitae, and Z. caudatus (Drew \& Romig, 2013; Saputra et al., 2019; Supratiwi et al., 2020). In order to easily recognize the fruit flies, an identification key is required especially the site specific one (Larasati et al., 2016). Identification of a species was needed to determine population control strategy and quarantine restrictions. The existence of a location-specific fruit flies identification key, especially in Central Bangka Regency, would be useful to accelerate the fruit flies identification process and find out information related to their taxonomy, particularly pest status and pest categories. Central Bangka Regency was one of the citrus producers in the Bangka Belitung Islands Province and the information about fruit flies in this area was still limited. This study aimed to determine the distribution and make dichotomous identification keys of fruit flies in Central Bangka District, especially in citrus plantation.

\section{MATERIALS AND METHODS}

Research Site. The research was conducted from April to October 2020 in Central Bangka Regency, Bangka Belitung Islands. Fruit flies identification was carried in the Laboratory of Agrotechnology, Faculty of Agriculture, Fisheries and Biology, Universitas Bangka Belitung. The location of this research was a citrus plantation owned by farmers in three villages producing orange in Central Bangka Regency, that are Nibung, Penyak, and Terentang. Each village consists of four farmer plantation area, so there are 12 research locations (Figure 1; Table 1). The research was conducted at citrus plantation with minimum area of $500 \mathrm{~m}^{2}$. Citrus plant in Central Bangka Regency were planted as an intercropping between pepper plants (Piper nigrum) and close to secondary forests, oil palm plantations, coconut plantations, and rubber plantations. Horticultural plants that located around the citrus plantation that ware found in very limited numbers (1-5 plants) consist of different kind species such as watery rose apple var citra/cincalo (Syzygium aqueum), malay rose apple var jamaika (S. malaccense), mango (Mangifera indica), binjai (M. caesia), dragon fruit (Hylocereus

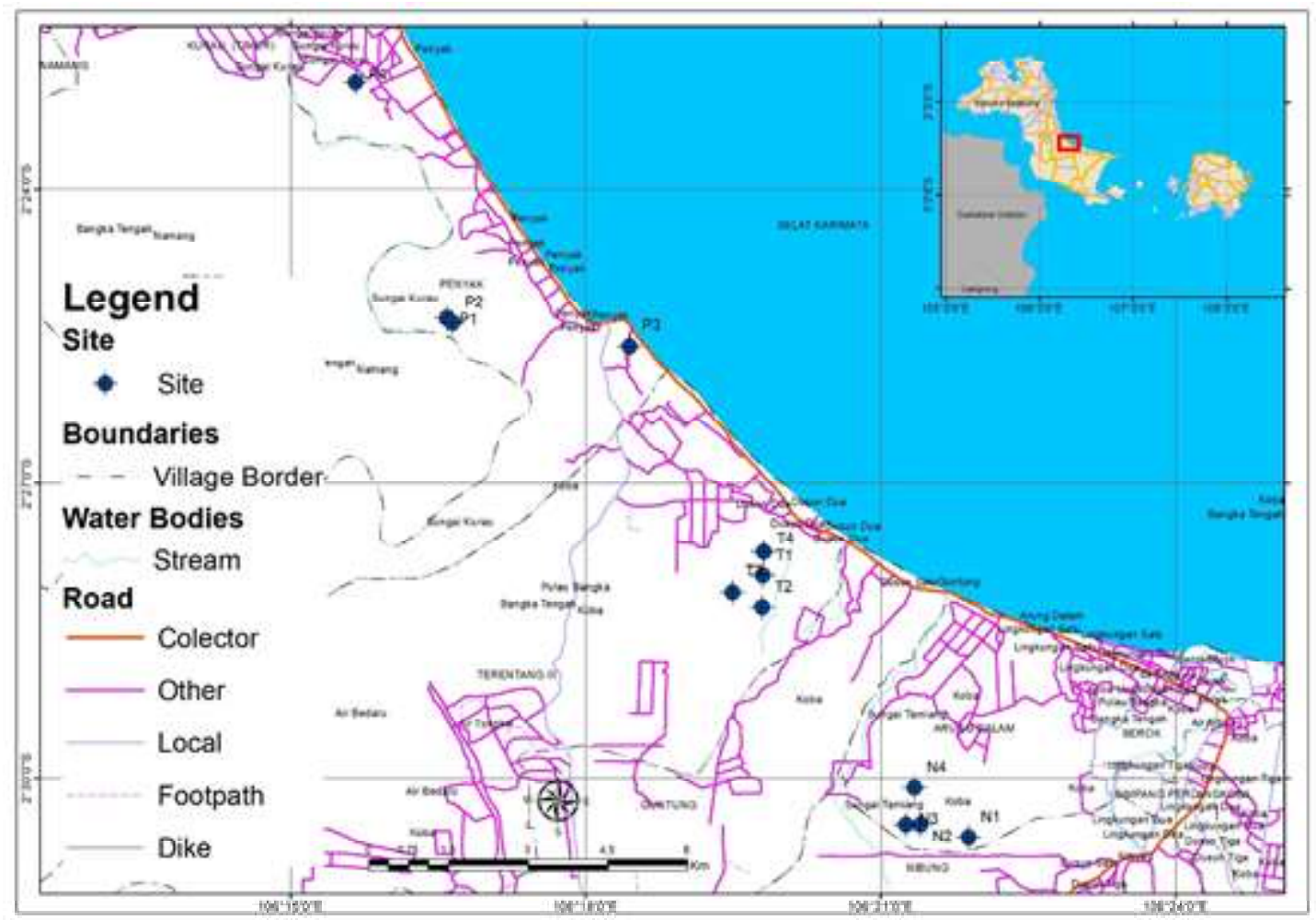

Figure 1. Map of research locations in Central Bangka Regency. 
polyrhizus), jeruk kunci (Citrus sp.), oyong (Luffa acutangula), cempedak (Artocarpus integer), pineapple (Ananas comosus), chilli (Capsicum frutescens) and eggplant (Solanum melongena).

Fruit Flies Trap. The type of fruit flies trap used was the lynfield trap. The traps were made from $550 \mathrm{~mL}$ clear plastic cups with 8 inlets. Each trap inserted with a dental cotton, $1 \mathrm{~mL}$ of attractant and $0.5 \mathrm{~mL}$ of deltamethrin $25 \mathrm{EC}$ then dropped using a plastic pipette. The placement of attractant traps was refered to Saputra et al. (2019), which in one cardinal direction, one attractant trap was installed. Each location consisted of 4 attractant traps, consist of 2 methyl eugenol attractant traps and 2 cue lure attractant traps. The distance between each methyl eugenol trap was $20 \mathrm{~m}$, and the installation of a cue lure attractant was also $20 \mathrm{~m}$ between each cue lure attractant trap. Distance between ME and cue lure trap was $14 \mathrm{~m}$. One methyl eugenol or cuelure attractant trap was installed on citrus plants and the other was attached to $3 / 4$ inch pvc pipe about $1.5 \mathrm{~m}$ above ground level. The attractant traps in each location were installed for 3 weeks and the trapped fruit flies were collected once a week. Fruit flies trapped in the attractant trap were put in an insect collection bottle and placed in an incubator at a temperature of \pm $40{ }^{\circ} \mathrm{C}$.

Fruit Flies Identification. The number of fruit flies obtained during the study was 4957 individuals. Fruit flies were identified morphologically using a stereo microscope. The observed characters were facial spots, thorax, abdomen, limbs, and wings. Fruit flies identification was carried out using dichotomous keys adopted from books, theses, and publications containing fruit flies identification keys (Drew \& Hancock, 1994; AQIS, 2008; Plant Health Australia, 2011; Drew \& Romig, 2013; Khaeruddin, 2015; Drew \& Romig, 2016; Larasati et al., 2016; Plant Health Australia, 2018; IPPC, 2019). The specimen vouchers of identified fruit flies were created by direct pinning or undirect pinning methods. Specimens were deposited in the Agrotechnology Laboratory, Faculty of Agriculture, Fisheries and Biology, Universitas Bangka Belitung.

Analysis. The fruit flies species data obtained were presented descriptively, including the distribution data of fruit flies in the Bangka Belitung Island, and the dichotomous key for the identification of fruit flies in Central Bangka Regency.

\section{RESULTS AND DISCUSSION}

The previous studies was reported 10 species of Dacini tribe fruit flies on Bangka Island i.e. $B$. albistrigata, $B$. atrifemur, $B$ carambolae, B. dorsalis, B. limbifera, B. occipitalis, B. umbrosa, Dacus nanggalae, Z. caudatus, and Z. cucurbitae. (Drew \& Romig, 2013; Saputra et al., 2019; Supratiwi et al., 2020). Our study in Central Bangka Regency, have obtained 14 species of fruit flies. Moreover, 5 of the observed species not yet reported previously on

Table 1. Research location in Central Bangka Regency

\begin{tabular}{|c|c|c|c|}
\hline Village & \multirow{2}{*}{ Longitude (E) } & \multirow{2}{*}{ Latitude (S) } & \multirow{2}{*}{ Altitude (m) } \\
\hline Citrus plantation site & & & \\
\hline \multicolumn{4}{|l|}{ Nibung $(\mathrm{N})$} \\
\hline 1 & $106^{\circ} 21^{\prime} 53,626^{\prime \prime} \mathrm{E}$ & $2^{\circ} 30^{\prime} 36,252^{\prime \prime} \mathrm{S}$ & 27 \\
\hline 2 & $106^{\circ} 21^{\prime} 24,088^{\prime \prime} \mathrm{E}$ & $2^{\circ} 30^{\prime} 28,264^{\prime \prime} \mathrm{S}$ & 25 \\
\hline 3 & $106^{\circ} 21^{\prime} 15,534^{\prime \prime} \mathrm{E}$ & $2^{\circ} 30^{\prime} 28,508^{\prime \prime} \mathrm{S}$ & 28 \\
\hline 4 & $106^{\circ} 21^{\prime} 20,621^{\prime \prime} \mathrm{E}$ & $2^{\circ} 30^{\prime} 05,893 " \mathrm{~S}$ & 16 \\
\hline \multicolumn{4}{|l|}{ Penyak (P) } \\
\hline 1 & $106^{\circ} 16^{\prime} 35,263^{\prime \prime} \mathrm{E}$ & $2^{\circ} 25^{\prime} 18,559^{\prime \prime} \mathrm{S}$ & 20 \\
\hline 2 & $106^{\circ} 16^{\prime} 38,752^{\prime \prime} \mathrm{E}$ & $2^{\circ} 25^{\prime} 21,497^{\prime \prime} \mathrm{S}$ & 10 \\
\hline 3 & $106^{\circ} 18^{\prime} 26,716^{\prime \prime} \mathrm{E}$ & $2^{\circ} 25^{\prime} 35,569^{\prime \prime} \mathrm{S}$ & 13 \\
\hline 4 & $106^{\circ} 15^{\prime} 39,816^{\prime \prime} \mathrm{E}$ & $2^{\circ} 22^{\prime} 54,696^{\prime \prime} \mathrm{S}$ & 6 \\
\hline \multicolumn{4}{|l|}{ Terentang $(\mathrm{T})$} \\
\hline 1 & $106^{\circ} 19^{\prime} 47,964^{\prime \prime} \mathrm{E}$ & $2^{\circ} 27^{\prime} 55,750^{\prime \prime} \mathrm{S}$ & 20 \\
\hline 2 & $106^{\circ} 19^{\prime} 47,654^{\prime \prime} \mathrm{E}$ & $2^{\circ} 28^{\prime} 15,384^{\prime \prime} \mathrm{S}$ & 18 \\
\hline 3 & $106^{\circ} 19^{\prime} 29,716^{\prime \prime} \mathrm{E}$ & $2^{\circ} 28^{\prime} 06,121^{\prime \prime} \mathrm{S}$ & 21 \\
\hline
\end{tabular}


Bangka Island that are B. fuscitibia, B. melastomatos, $B$. neocognata, $B$. nigrotibialis, and $Z$. apicalis. Based on reference tracing and research findings, the number of fruit flies species on Bangka Island was now 15 species. The 15 species were shown in Table 2.

The number of fruit flies species obtained during the research in the citrus plantation in Central Bangka Regency were 3 genera and 14 species (Table 2; Figure $2)$. Fruit flies that trapped in ME were identified as $B$. atrifemur, B. carambolae, B. dorsalis, B. occipitalis, and B. umbrosa. Meanwhile, fruit flies that trapped in the cue lure were identified as B. albistrigata, B. fuscitibia, B. melastomatos, $B$. neocognata, $B$. nigrotibialis, D. nanggalae, $Z$. apicalis, $Z$. caudatus, and Z. cucurbitae. The fruit flies species obtained in this study were trapped only in one type of attractant. This result was in line with the publication of Doorenweerd et al. (2018), that these species were only interested in one attractant, such as cue lure or ME alone, and no fruit flies that were attracted to both $\mathrm{ME}$ and cue lure.

On ME attractant, $B$. atrifemur was obtained in Terentang Village, while $B$. carambolae, $B$. dorsalis, B. occipitalis, and B. umbrosa were obtained at three study sites (Figure 2a). The first report of B. atrifemur in Indonesia was in Kace, Mendo Barat, Bangka Regency, Bangka in 2006 on a ME trap in the cempedak plant area (Drew \& Romig, 2013). Cempedak plants were also found in the vicinity of the research location, at locations 3 and 4 of citrus plantations in Terentang Village (Table 1; Figure 2a). Thus, it becomes a new note that the $B$. atrifemur were not only distributed in Bangka Regency, but also in Central Bangka Regency. Bangka Regency, but also in Central Bangka Regency. In cue lure attractants, $B$. melastomatos were obtained in Nibung Village while B. nigrotibialis, D. nanggalae, and $Z$. cucurbitae were obtained in Terentang Village. The Z. apicalis were obtained in Penyak and Terentang Villages. In the other hand, B. albistrigata, B. fuscitibia, $B$. neocognata, and $Z$. caudatus were obtained in three study sites (Figure $2 b$ ). The results of this study showed that the cue lure attractant was favored by the three genus of fruit flies: Bactrocera, Dacus, and Zeugodacus, while ME were favored by the genus Bactrocera. Cue lure attractants were the dominant attractants in various species in the genus Dacus and Zeugodacus, and only a few species of this genus were interested in ME attractants (Drew \& Romig, 2013; Drew \& Romig, 2016; Doorenweerd et al., 2018). Doorenweerd et al. (2018) reported that ME was also preferred by various species of the genus Zeugodacus, but in this study it had not been found. The number of fruit flies species that have been found in Indonesia were 122 species (Drew \& Romig, 2012a).

In Indonesia, 122 species of Dacini fruit flies were reported and 11 of them were classified as important pests (Drew \& Romig, 2012a). The eleven fruit flies were B. albistrigata, B. carambolae, B. dorsalis, B. frauenfeldi, B. latifrons, B. musae, B. occipitalis, B. umbrosa, Z. caudatus, Z. cucurbitae, and Z. tau (Drew \& Romig, 2012b). In Indonesia, Drew \& Romig (2012a) explained that (1) B. albistrigata, $B$. frauenfeldi, and $B$. umbrosa were minor pests, (2) B. carambolae, B. dorsalis, B. occiptalis, and Z. cucurbitae were major pests, (3) Z. caudatus confirmed breeding in flowers cucurbits, not fruits/ vegetables for export, (4) B. musae is a species with a limited distribution in Papua, (5) B. occipitalis was a pest species that was limited in distribution in Kalimantan.

Based on the Regulation of the Minister of Agriculture of the Republic of Indonesia Number 25 year 2020 concerning Types of Quarantined Plant Destruction Organisms that $B$. occipitalis was a type of $B$. dorsalis complex which was only found in Kalimantan, Indonesia (Kementerian Pertanian Republik Indonesia, 2020). Not only in Kalimantan, B. occipitalis was reported to be existed in several regions of Indonesia based on morphological identification (Table 2), but for determination in whether this species had entered another region in Indonesia molecular identification may be provided (Martiningsia et al., 2017). Species identification by morphological identification in the $B$. dorsalis complex was partly difficult due to the high degree of diversity of characters within species and the overlapping morphological characters between species (IPPC, 2019). The same species had variations in the morphological character of the pattern and color both on the scutum and abdomen, and sometimes looks similar to other species (Drew \& Hancock, 1994; Leblanc et al., 2015; Plant Health Australia, 2018; IPPC, 2019; Nakahara et al., 2019). Morphologically, $B$. occipitalis had similar to $B$. carambolae, $B$. fuscitibia, B. arecae and B. atrifemur (Drew \& Hancock, 1994; Drew \& Romig, 2012a; Plant Health Australia, 2018). The B. carambolae, B. papayae, $B$. melastomatos, and $B$. philippinensis could be identified as $B$. occipitalis due to misidentification (Drew \& Hancock, 1994). Misidentification occured because all of these species have costal bands that overlap $\mathrm{R}_{2}+{ }_{3}$ and varying in width of costal band overlapping $\mathrm{R}_{2}+{ }_{3}$, and marking abdominal terga III $\mathrm{V}$ sometimes similar to another species of Bactrocera (Drew \& Hancock, 1994; Plant Health Australia, 2018; 
Table 2. Distribution, status and categories of fruit fly pests in Indonesia and Bangka Island

\begin{tabular}{|c|c|c|c|c|c|c|}
\hline No & Species & $\begin{array}{c}\text { Male } \\
\text { attractant }\end{array}$ & $\begin{array}{l}\text { Distribution in } \\
\text { Indonesia }^{\text {a }}\end{array}$ & Pest status ${ }^{\mathbf{b}}$ & $\begin{array}{c}\text { Pest } \\
\text { category }\end{array}$ & $\begin{array}{l}\text { Distribution on } \\
\text { Bangka Island }{ }^{\mathbf{d}}\end{array}$ \\
\hline 1 & $\begin{array}{l}\text { Bactrocera } \\
\text { abistrigata de } \\
\text { Meijere, } 1911\end{array}$ & cue lure & $\begin{array}{l}\text { (Jawa, Kalimantan, } \\
\text { Sulawesi, dan Lesser } \\
\text { Sunda)*, Bangka } \\
\text { Islands** }\end{array}$ & $\begin{array}{l}\text { Fruit pest } \\
\text { (polyphagous) }\end{array}$ & $\mathrm{C}$ & $\begin{array}{l}\text { Central Bangka } \\
\text { Regency, Bangka } \\
\text { Regency }\end{array}$ \\
\hline 2 & $\begin{array}{l}\text { Bactrocera } \\
\text { atrifemur Drew \& } \\
\text { Hancock, } 1994\end{array}$ & ME & (Bangka Islands)*/** & Non-Pest & - & $\begin{array}{l}\text { Central Bangka } \\
\text { Regency, Bangka } \\
\text { Regency }\end{array}$ \\
\hline 3 & $\begin{array}{l}\text { Bactrocera } \\
\text { carambolae Drew \& } \\
\text { Hancock, } 1994\end{array}$ & $\mathrm{ME}$ & $\begin{array}{l}\text { (Bali, Jawa, } \\
\text { Kalimantan, Maluku, } \\
\text { Maluku Utara, } \\
\text { Sulawesi, Sumatra, } \\
\text { Papua)*, Bangka } \\
\text { Islands** }\end{array}$ & $\begin{array}{l}\text { Fruit pest } \\
\text { (polyphagous) }\end{array}$ & A & $\begin{array}{l}\text { Central Bangka } \\
\text { Regency, Bangka } \\
\text { Regency }\end{array}$ \\
\hline 4 & $\begin{array}{l}\text { Bactrocera dorsalis } \\
\text { (Hendel, 1912) }\end{array}$ & ME & $\begin{array}{l}\text { (Bali, Jawa, } \\
\text { Kalimantan, Maluku } \\
\text { Utara, Sulawesi, } \\
\text { Sumatra, West } \\
\text { Timor, Papua, Lesser } \\
\text { Sunda)*, Bangka } \\
\text { Islands** }\end{array}$ & $\begin{array}{l}\text { Fruit pest } \\
\text { (polyphagous) }\end{array}$ & A & $\begin{array}{l}\text { Central Bangka } \\
\text { Regency, Bangka } \\
\text { Regency }\end{array}$ \\
\hline 5 & $\begin{array}{l}\text { Bactrocera } \\
\text { fuscitibia } \text { Drew \& } \\
\text { Hancock, } 1994\end{array}$ & cue lure & $\begin{array}{l}\text { (Bali, Jawa, } \\
\text { Kalimantan, } \\
\text { Sulawesi, Sumatra)*, } \\
\text { Bangka Islands** }\end{array}$ & Non-Pest & - & $\begin{array}{l}\text { Central Bangka } \\
\text { Regency }\end{array}$ \\
\hline 6 & $\begin{array}{l}\text { Bactrocera } \\
\text { limbifera (Bezzi, } \\
1919)\end{array}$ & cue lure & $\begin{array}{l}\text { (Jawa, Kalimantan, } \\
\text { Sulawesi, Sumatra, } \\
\text { Lesser Sunda)*, } \\
\text { Bangka Islands }\end{array}$ & Non-Pest & - & Bangka Regency \\
\hline 7 & $\begin{array}{l}\text { Bactrocera } \\
\text { melastomatos Drew } \\
\text { \& Hancock, } 1994\end{array}$ & cue lure & $\begin{array}{l}\text { (Jawa, Kalimantan, } \\
\text { Sumatra)*, Bangka } \\
\text { Islands** }\end{array}$ & Non-Pest & - & $\begin{array}{l}\text { Central Bangka } \\
\text { Regency }\end{array}$ \\
\hline 8 & $\begin{array}{l}\text { Bactrocera } \\
\text { neocognata } \text { Drew \& } \\
\text { Hancock, } 1994\end{array}$ & cue lure & $\begin{array}{l}\text { (Jawa, Kalimantan, } \\
\text { Lesser Sunda)*, } \\
\text { Bangka Islands** }\end{array}$ & Non-Pest & - & $\begin{array}{l}\text { Central Bangka } \\
\text { Regency }\end{array}$ \\
\hline 9 & $\begin{array}{l}\text { Bactrocera } \\
\text { nigrotibialis } \\
\text { (Perkins, 1938) }\end{array}$ & cue lure & $\begin{array}{l}\text { (Kalimantan, } \\
\text { Sumatra, Lesser } \\
\text { Sunda)*, Bangka } \\
\text { Islands** }\end{array}$ & $\begin{array}{l}\text { Fruit pest } \\
\text { (oligophagous) }\end{array}$ & $\mathrm{D}$ & $\begin{array}{l}\text { Central Bangka } \\
\text { Regency }\end{array}$ \\
\hline 10 & $\begin{array}{l}\text { Bactrocera } \\
\text { occipitalis (Bezzi, } \\
1919)\end{array}$ & ME & $\begin{array}{l}(\text { Kalimantan })^{*}, \\
\text { (Bangka Islands)** } \\
(\text { Jawa, Sulawesi, } \\
\text { Sumatra)*** }\end{array}$ & $\begin{array}{l}\text { Fruit pest } \\
\text { (polyphagous) }\end{array}$ & $\mathrm{B}$ & $\begin{array}{l}\text { Central Bangka } \\
\text { Regency, Bangka } \\
\text { Regency }\end{array}$ \\
\hline 11 & $\begin{array}{l}\text { Bactrocera umbrosa } \\
\text { (Fabricius, 1805) }\end{array}$ & $\mathrm{ME}$ & $\begin{array}{l}\text { (Bali, Jawa, } \\
\text { Kalimantan, Maluku, } \\
\text { Maluku Utara, } \\
\text { Sulawesi, Sumatra, } \\
\text { West Timor, Papua, } \\
\text { Lesser Sunda)*, } \\
\text { Bangka Islands** }\end{array}$ & $\begin{array}{l}\text { Fruit pest } \\
\text { (monophagous) }\end{array}$ & $\mathrm{C}$ & $\begin{array}{l}\text { Central Bangka } \\
\text { Regency, Bangka } \\
\text { Regency }\end{array}$ \\
\hline
\end{tabular}


Table 2. Distribution, status and categories of fruit fly pests in Indonesia and Bangka Island (continue)

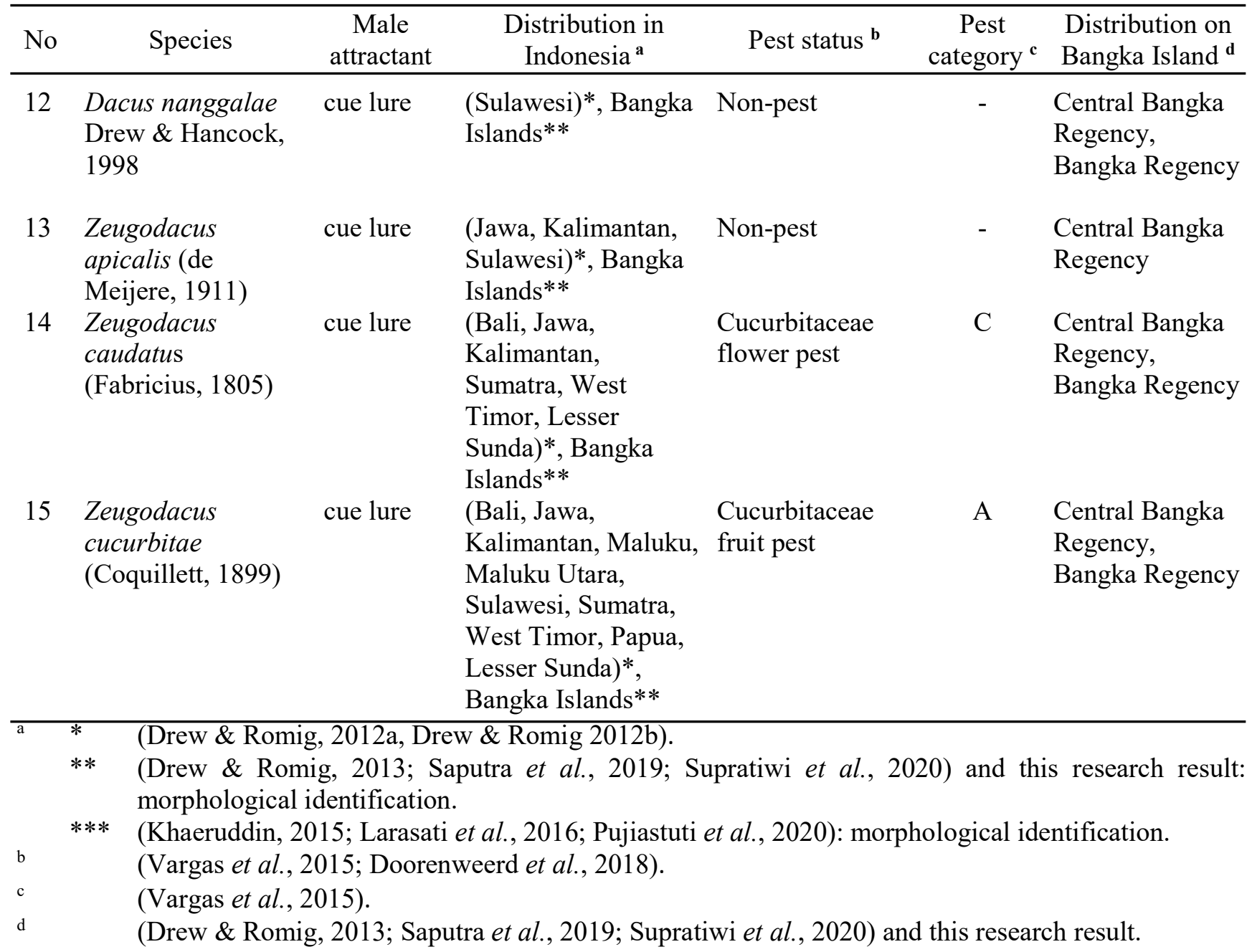

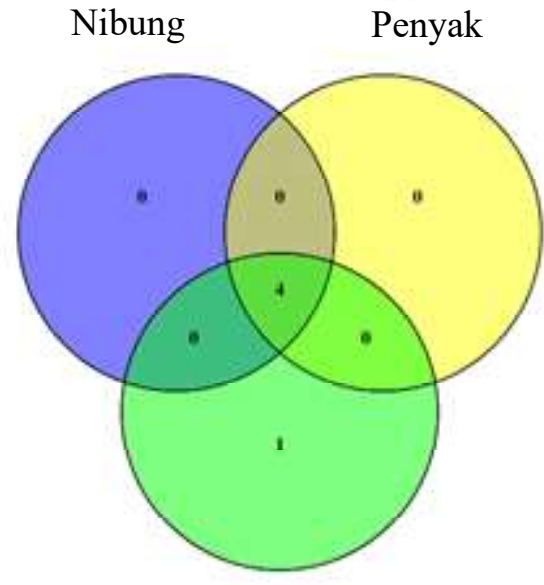

A Terentang

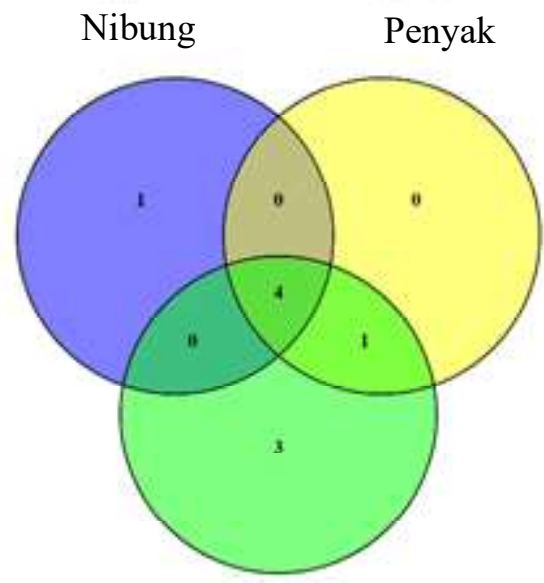

B

Terentang

Figure 2. Distribution of fruit flies by type of attractant in the three research locations. (A) Methyl eugenol; (B) Cue lure. 
Nakahara et al., 2019). The morphological character of B. occipitalis that differentiates it from other B. dorsalis complex species could be seen in Drew \& Hancock (1994).

The highest number of fruit flies species were obtained in the citrus plantation in Terentang Village, that were 13 species. Meanwhile, the number of fruit flies species obtained in the citrus plantations in Nibung and Penyak Villages were 9 species. The fruit flies species found in the citrus plantation in Nibung village were B. albistrigata, B. carambolae, B. dorsalis, $B$. fuscitibia, B. melastomatos, B. neocognata, B. occipitalis, B. umbrosa, and Z. caudatus. While in Penyak village were $B$. albistrigata, $B$. carambolae, $B$. dorsalis, $B$. fuscitibia, $B$. neocognata, B. occipitalis, B. umbrosa, Z. apicalis, and $Z$. caudatus. On the other hand the fruit flies species found in Terentang Village were B. albistrigata, B. atrifemur, B. carambolae, B. dorsalis, B. fuscitibia, $B$. neocognata, B. nigrotibialis, B. occipitalis, B. umbrosa, D. nanggalae, Z. apicalis, Z. caudatus, and $Z$. cucurbitae.

The number of fruit flies obtained in Central Bangka Regency were 14 species and 7 species of which were $B$. dorsalis complex, namely B.atrifemur, $B$ carambolae, B. dorsalis, B. fuscitibia, $B$. melastomatos, $B$. neocognata, and B. occipitalis. The species of $B$. dorsalis complex could be characterized by the pressence of $\mathrm{T}$ pattern on the abdomen with III-IV, the medial vittae in the thorax was absent and present lateral vittae in the thorax, and the scutelum was yellowish (IPPC, 2019). The genera obtained in this study were Bactrocera, Dacus, and Zeugodacus. The genus Dacus is easily recognized from the part of the abdomen which was strongly petiolate or elongate-oval and the terga fused on abdomen (AQIS, 2008; Drew \& Romig, 2013; Drew \& Romig, 2016). The genus Bactrocera easily recognized by the shape of the abdomen that is oval or elongateoval, the terga not fused on abdomen, and medial vittae in the thorax absent (AQIS, 2008; Drew \& Romig, 2013; Drew \& Romig, 2016). Whereas, the genus Zeugodacus is easily recognized by its oval or elongate-oval abdomen, the terga not fused on abdomen, and the presence of medial vittae in the thorax (AQIS, 2008; Drew \& Romig, 2013; Drew \& Romig, 2016). As for the identification keys of the fourteen fruit flies species based on attractant preferences in Central Bangka, Bangka was shown as follows:
The dichotomous key to identify the Dacini tribe fruit flies based on its attractant preferences in Central Bangka, Bangka

1a. Fruit flies were attracted to methyl eugenol attractant........................................................2

1b. Fruit flies are attracted to cue lure attractant.......6

2a. Abdominal terga III-IV without T pattern, wing with three additional bands from the costal band towards hind margin: Figure $3 \mathrm{~A}$.

Bactrocera umbrosa

2b. Abdominal terga III-IV with T pattern, wing without additional band from the costal band towards the hind margin....

\section{3}

3a. Femora glossy black that is on $3 / 4$ of the fore femora from the apical, $1 / 3$ of the middle femora from the apical, and $2 / 5$ of the hind femora from the apical: Figure 3B..... Bactrocera atrifemur

3b. Femora reddish yellow /fulvous or reddish yellow with a dark pattern/ dark fuscous.

4a. Costal band confluent with R2 + 3: Figure $3 \mathrm{C}$ Bactrocera dorsalis

4b. Costal band overlapping with R2 + 3....................

5a. Abdominal terga III-V with a very wide medial longitudinal and lateral dark margins is wide; costal band continuous and extending to the tip of the wing: Figure 3D Bactrocera occipitalis

5b. Abdominal terga III-V with medium medial longitudinal; anterolateral terga IV is rectangle shape; costal band continuous and extends only at the ends of R4 + 5: Figure 3E

Bactrocera carambolae

6a . Abdominal terga fused, abdomen petiolate; costal band overlapping R4 + 5; abdominal terga III-V red brown with a narrow longitudinal medial: Figure $3 \mathrm{~F}$. Dacus nanggalae

$6 \mathrm{~b}$. Abdominal terga not fused, abdomen oval...............7

7a . Thorax with medial longitudinal vitae......................8

7b. Thorax without medial longitudinal vitae...............10

8a. Costal band broken after the $\mathrm{R} 2+3$ tip and there is a large spot on the wingtip: Figure 3G..................................eugodacus apicalis

$8 \mathrm{~b}$. Costal band continuous up to the edge of the wing... 9 
9a. Facial spots converge; no additional band on dmcu: Figure $3 \mathrm{H}$... Zeugodacus caudatus

9b. Facial spots don't merge, two black spot; there is an additional band on dm-cu: Figure 3I. Zeugodacus cucurbitae

10a. Abdominal terga III-IV without a T pattern .......11

10b. Abdominal terga III-IV with a T pattern. 11a. Wing with one additional band from the costal band towards the edge of the wing edge: Figure 3J Bactrocera albistrigata

$11 \mathrm{~b}$. Wing without additional band from the costal band towards the edge of the wing; hind femora in black at $1 / 3$ to $1 / 2$ from the apical:

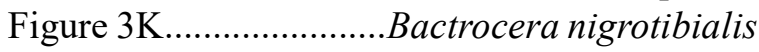
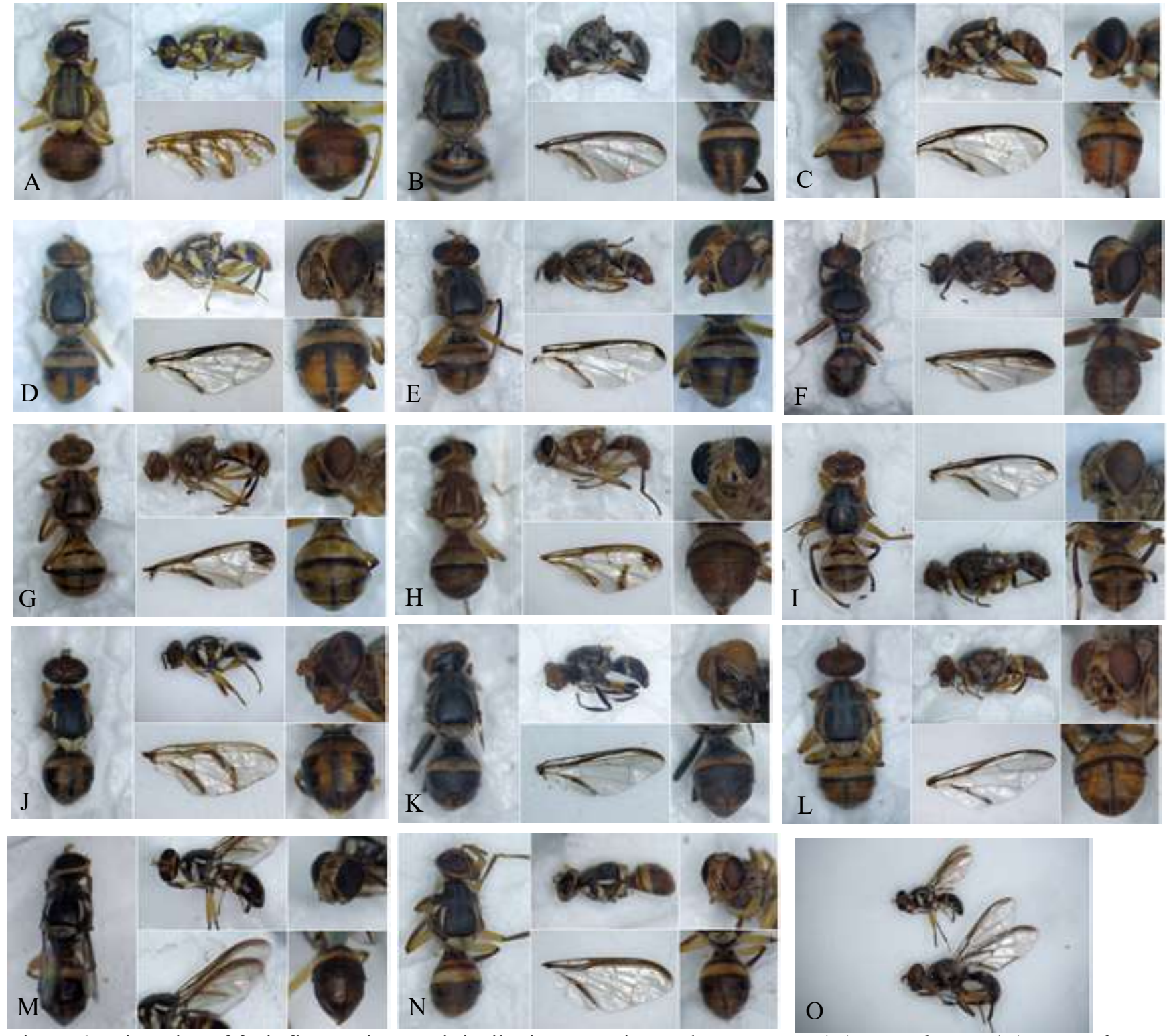

Figure 3. Diversity of fruit fly species Dacini tribe in Central Bangka Regency. (A) B. umbrosa; (B) B. atrifemur;

(C) B. dorsalis; (D) B. occipitalis; (E) B. carambolae; (F) D. nanggalae; (G) Z. apicalis;

(H) Z. caudatus; (I) Z. cucurbitae; (J) B. albistrigata; (K) B. nigrotibialis; (L) B. fuscitibia;

(M) B. melastomatos; (N) B.neocognata; (O) body size comparison B. melastomatos (above) and B. neocognata (below). 
12a. Lateral postsutural vittae paralel: Figure 3L Bactrocera fuscitibia

12b. Lateral postsutural vittae narrows posteriorly before i.a setae. .13

13a. Costal band clearly exceeds $\mathrm{R} 2+3$ and not until $\mathrm{R} 4+5$, and at the wingtips costal band widened: Figure $3 \mathrm{M}$ Bactrocera melastomatos

13b. Costal band just overlapping R2 +3 : Figure $3 \mathrm{~N}$ Bactrocera neocognata

The dichotomous is the key of determination that is created for the user to be able to determine and recognize an organism (Griffing, 2011). This key consists of a specific set of questions with two questions and lead the user to a species, genus, family, or order of an organism. The questions contained in the dichotomy key are arranged in pairs and show opposite characters. The dichotomous keys are made sequentially starting from general characters to specific characters. An organism with the most unique character among the others will be placed first in the dichotomous key. In fruit flies, dichotomous keys can be made from the characters on the head, scutum, scutellum, femora, wings, abdomen, and genitalia (Drew \& Hancock, 1994; IPPC, 2015; Drew \& Romig, 2016; Plant Health Australia, 2018). In this study, dichotomous key was made based on the type of male fruit fly attractant to be used easily in determining fruit fly species.

\section{CONCLUSION}

The diversity of fruit flies species tribe Dacini in Central Bangka Regency, Bangka was 3 genera and 14 species. Based on morphological identification, fruit flies that trapped in the methyl eugenol attractant trap were identified as B. atrifemur, B. carambolae, B. dorsalis, B. occipitalis, and B. umbrosa. Meanwhile, fruit flies that trapped in cue lure attractant traps were identified as $B$. albistrigata, B. fuscitibia, B. melastomatos, $B$. neocognata, $B$. nigrotibialis, D. nanggalae, $Z$. apicalis, Z. caudatus, and Z. cucurbitae. Seven of the fourteen species of fruit flies found in Central Bangka Regency are $B$. dorsalis complex. All fruit fly species obtained were presented with a dichotomous identification key based on male fruit fly attractants.

\section{ACKNOWLEDGMENTS}

This research was funded by the Ministry of Research and Technology/National Research and Innovation Agency, KEMENRISTEK-BRIN, with scheme young lecture research based on Decree Number: 7.15/UN50/PG/IV/2020 and Agreements Number: 035/SP2H/LT/DRPM/2020. We are thankful to (1) the orange farmers who have allowed their plantation area to be used as research locations; (2) agricultural extension on behalf of Heri, S. P. who have helped find suitable citrus orchards as research locations, assisted in the installation of attractant traps and collection of fruit fly specimens, and (3) other colleagues at the Koba Agricultural Extension Center (BPP), Food Service, Central Bangka Regency Government.

\section{REFERENCES}

AQIS. 2008. Third Training Workshop Fruit Flies of Indoneisa: their Identification, Pest Managent. Griffith University, Australia-Ministry of Agiculture Republic of Indonesia, Brisbane.

Doorenweerd C, Leblanc L, Norrbom AL, San Jose M, \& Rubinoff D. 2018. A global checklist of the 932 fruit fly species in the tribe Dacini (Diptera, Tephritidae). ZooKeys. 730: 19-56.

Drew RAI \& Hancock DL. 1994. The Bactrocera dorsalis complex of fruit flies (Diptera: Tephritidae: Dacinae) in Asia. Bull. Entomol. Res. 83 (2): 1-68.

Drew RAI \& Romig MC. 2012a. Fruit Fly Species (Diptera: Tephritidae: Dacinae) Recorded in Indonesia. In: Griffith University (Eds.). Training Workshop Fruit Flies of Indonesia: their Identification, Pest Status and Pest Management. pp. 45-52. Grifffith University, Brisbane, Australia.

Drew RAI \& Romig MC. 2012b. Diagnoses of Pest Species. In: Griffith University (Eds.). Training Workshop Fruit Flies of Indonesia: their Identification, Pest Status and Pest Management. pp. 73-170. Grifffith University, Brisbane, Australia. 
Drew RAI \& Romig MC. 2013. Tropical Fruit Flies (Tephritidae: Dacinae) of Saouth-East Asia: Indomalaya to North-West Australasia. CABI, Wallingford.

Drew RAI \& Romig MC. 2016. Keys to Tropical Fruit Flies (Tephritidae: Dacinae) of South-East Asia: Indomalaya to North-West Australasia. CABI, Wallingford.

Griffing LR. 2011. Who invented the dichotomous key? Richard Waller's watercolors of the herbs of Britain. Am. J. Bot. 98(12): 1911-1923.

IPPC. 2015. ISPM 26: Establishment of Pest Free Areas for Fruit Flies (Tephritidae). International Plant Protection Convention.

IPPC. 2019. ISPM 27 Diagnostic protocols for regulated pests, DP 29: Bactrocera dorsalis. International Plant Protection Convention.

Kementerian Pertanian Republik Indonesia. 2020. Peraturan Menteri Pertanian Republik Indonesia Nomor 25 Tahun 2020 tentang Jenis Organisme Penganggu Tumbuhan Karantina. Kementerian Pertanian Republik Indonesia, Jakarta.

Khaeruddin. 2015. Identifikasi lalat buah (Diptera: Tephritidae) di beberapa Kabupaten di Provinsi Sulawesi Barat. Thesis. Institut Pertanian Bogor. Bogor.

Kwasi W. 2008. Assessment of fruit fly damage and implications for the dissemination of management practices for mango production in the Upper West Region of Ghana. J. Dev. Sus. Agr. 3(2): 117134.

Larasati A, Hidayat P, \& Buchori D. 2016. Kunci identifikasi lalat buah (Diptera: Tephritidae) di Kabupaten Bogor dan sekitarnya. JEI. 13(1): 4961.

Leblanc L, Jose MS, Barr N, \& Rubinoff D. 2015. A phylogenetic assessment of the polyphyletic nature and intraspecific color polymorphism in the Bactrocera dorsalis complex (Diptera, Tephritidae). ZooKeys. 540: 339-367.

Martiningsia D, Wijaya IN, \& Sudiarta IP. 2017. Karakteristik molekuler dan filogeni lalat buah Bactrocera occipitalis (Diptera: Tephritidae) dari Tarakan berdasarkan sekuen nukleotida gen COI. J. Agric. Sci. Biotechnol. 6(1): 18-26.
Nakahara S, Katayama M, Thein MM, Yee KN, Naing SS, Soe W, Htiek T, \& Tsuruta K. 2019. Notes on the genus Bactrocera fruit fly species in mango orchards in Myanmar. Res. Bull. Pl. Prot. Japan. 55: 43-51.

Ni M, Gu K, Hassan B, Ning D, Zheng Y, Qi Y, \& Xu Y. 2020. Effect of oviposition by Bactrocera dorsalis on the antioxidant activity of orange juice. Braz. J. Biol. 80(3): 641-647.

Omoloye AA, Oladapo OG, Ibitoye O, \& Alabi OY. 2016. Effects of field attack by Ceratitis capitata Wiedemann (Diptera: Tephritidae) on the morphology and nutritional quality fresh fruit of Citrus sinensis L. Afr. J. Agric. Res. 11(11): 967973.

Plant Health Australia. 2011. The Australian Handbook for the Identification of Fruit Flies Version 1.0. Plant Health Australia, Canberra.

Plant Health Australia. 2018. The Australian Handbook for the Identification of Fruit Flies Version 3.1. Plant Health Australia, Canberra.

Pujiastuti Y, Irsan C, Herlinda S, Kartini L, \& Yulistin E. 2020. Keanekaragaman dan pola keberadaan lalat buah (Diptera: Tephritidae) di Provinsi Sumatera. JEI. 17(3): 125-135.

Saputra HM, Sarinah, \& Hasanah M. 2019. Kelimpahan dan dominansi lalat buah (Diptera: Tephritidae) pada pertanaman cabai (Capsicum annuum L.), di Desa Paya Benua, Bangka. Agrosainstek. 3(1):36-41.

Supratiwi R, Apriyadi R, \& Asriani E. 2020. Fruit flies (Diptera: Tephritidae) diversity in horticultural farm of Merawang Sub-District, Bangka District, Bangka Belitung Islands. J. HPT Tropika. 20(1): 61-70.

Vargas RI, Mau RL, \& Jang EB. 2007. The Hawaii fruit fly area-wide pest management program: accomplishments and future directions. Proc. Hawaii. Entomol. Soc. 39: 99-104.

Vargas RI, Piñero JC, \& Leblanc L. 2015. An overview of pest species of Bactrocera fruit flies (Diptera: Tephritidae) and the integration of biopesticides with other biological approaches for their management with a focus on the Pacific region. Insects. 6(2): 297-318. 